\title{
Amalgamation and small-scale gold mining in the ancient Andes
}

Amalgación y minería de oro a pequeña escala en los Andes prehispánicos

Amalgame et mine d'or à petite échelle dans les Andes pré-hispaniques

William E. Brooks, Gabriela Schwörbel and Luis Enrique Castillo

\section{OpenEdition}

Electronic version

URL: http://journals.openedition.org/bifea/1471

DOI: 10.4000/bifea.1471

ISSN: 2076-5827

\section{Publisher}

Institut Français d'Études Andines

Printed version

Date of publication: 1 August 2011

Number of pages: 333-347

ISSN: 0303-7495

\section{Electronic reference}

William E. Brooks, Gabriela Schwörbel and Luis Enrique Castillo, « Amalgamation and small-scale gold mining in the ancient Andes », Bulletin de l'Institut français d'études andines [Online], 40 (2) | 2011, Online since 01 February 2012, connection on 07 November 2020. URL : http://journals.openedition.org/ bifea/1471 ; DOI : https://doi.org/10.4000/bifea.1471

\section{(c) $(1)$}

Les contenus du Bulletin de l'Institut français d'études andines sont mis à disposition selon les termes de la licence Creative Commons Attribution - Pas d'Utilisation Commerciale - Pas de Modification 4.0 International. 


\title{
Amalgamation and small-scale gold mining in the ancient Andes
}

\author{
William E. Brooks* \\ Gabriela Schwörbel** \\ Luis Enrique Castillo***
}

\begin{abstract}
In 1532, the volume of gold provided by Atahualpa, the Inka king, as ransom for his release from the Spanish was hard evidence for the efficient small-scale gold mining that took place before European contact and the number of gold occurrences in the Andes. At Huancavelica, Perú, mercury occurs as a native metal and as cinnabar [HgS], which was used for pigments, funeral preparations, and retorted to obtain mercury.

Using Inductively Coupled Plasma analysis (ICP), an average of 15 ppm (parts per million) mercury was found in the gold after the gold-mercury amalgam, with more than 300000 ppm mercury, was burned to volatilize (rogado) the mercury. From 12,3 to 13,9 ppm mercury was found in worked gold foils from Huaca la Ventana, a Middle Sicán (A. D. 900-1200) site at Lambayeque, Perú and low levels of mercury were found in pre-contact gold foils from Colombia (1-12 ppm). Similarly low levels of mercury in the analyses of modern refogado gold and pre-contact gold foils are consistent with a comparable, ancient small-scale mining technology that would have used mercury to amalgamate the fine-grained gold; and then, as now, burning the amalgam to volatilize the mercury and beautify and recover the gold.
\end{abstract}

Key words: amalgamation, mercury, Andes, small-scale gold mining

* Geologist, Reston, VA 20191. E-mail: webgeology@aim.com

** Museo Nacional de Arqueología, Lima, Perú. E-mail: gschworbel@mcultura.gob.pe

***Museo Nacional de Arqueología, Lima, Perú. E-mail: Icastillo@mcultura.gob.pe 


\section{Amalgación y minería de oro a pequeña escala en los Andes prehispánicos}

\section{Resumen}

En 1532, el volumen de oro proporcionado por el Inca Atahualpa, como rescate por liberarlo de los españoles, fue una prueba difícil para la minería de oro eficiente a pequeña escala que tuvo lugar antes del contacto europeo y la cantidad de oro disponible en los Andes. En Huancavelica, Perú, el mercurio se presenta como un metal nativo y como cinabrio ( $\mathrm{HgS})$, que fue utilizado para los pigmentos, los preparativos funerarios y para obtener mercurio.

Utilizando el análisis llamado Induced Coupled Plasma (ICP), un promedio de 15 ppm (partes por millón) de mercurio fue encontrado en el oro después de que la amalgama oro-mercurio (>300 000 ppm de mercurio) haya sido quemada o refogada para volatilizar el mercurio, en las tiendas modernas de oro en Madre de Dios, Perú. De 12,3 a 13,9 ppm de mercurio fue encontrado en láminas de oro trabajado en Huaca la Ventana, Sican Medio (900-1200 d. C.), Lambayeque, Perú y bajos niveles de mercurio fueron encontrados en las láminas pre-contacto de oro de Colombia (1-12 ppm) y Ecuador. Asimismo, los bajos niveles de mercurio medidos en el análisis ICP de oro refogado moderno (charapitas) y precontacto (láminas de oro) son consistentes con los valores esperados utilizando una antigua tecnología de pequeña minería. Para eso se usa métodos de separación por gravedad y de amalgama de mercurio para el tratamiento del grano fino y vena de oro de los lavaderos, y entonces, como ahora, el refogado de la amalgama hace volitilizar el mercurio, para embellecer y recuperar el oro.

Palabras clave: mercurio, oro, amalgamación, geoquimíca

\section{Amalgame et mine d'or à petite échelle dans les Andes pré- hispaniques}

\section{Résumé}

En 1532, la quantité de I'or fourni par Atahualpa, le souverain Inka, pour payer sa rançon aux Espagnols constitua une dure épreuve pour l'industrie minière à petite échelle à l'époque pré-hispanique et un indicateur de la quantité d'or disponible dans les Andes. À Huancavelica, au Pérou, le mercure est considéré comme un métal d'origine et comme du cinabre (HgS), utilisé pour les pigments, pour les préparatifs funéraires et pour obtenir du mercure.

L'analyse par spectrométrie de masse à plasma inductif (ICP) d'échantillons modernes produits dans les ateliers de traitement d'or à Madre de Dios, Pérou, révèle la présence d'une valeur moyenne de 15 ppm de mercure dans l'or, après que l'amalgame a été brûlé (refogado), afin de volatiliser le mercure (>300 000 ppm de mercure). Par ailleurs, des concentrations de mercure entre 12 et 14 ppm ont été mesurées dans les feuilles d’or de la Huaca la Ventana, Pérou, un site Lambayeque Sicán moyen (900-1200 ap. J.-C.) et entre 1 et 12 ppm dans les feuilles d'or trouvées en Colombie et en Équateur à l'époque pré-hispanique. Les basses concentrations de mercure mesurées par ICP pour l'or refogado moderne et pour des feuilles d'or de l'époque pré-contact sont conformes aux valeurs attendues pour une technologie ancienne d'extraction à petite échelle qui aurait utilisé les méthodes de séparation par gravité et d'amalgame de mercure pour traitement de la fine poudre d'or des gisements et des filons; il s'agissait donc, comme actuellement, de brûler l'amalgame de façon à volatiliser le mercure et récupérer l'or.

Mots clés : mercure, or, amalgame, géochimie 


\section{INTRODUCTION}

Placer gold was early man's main source of gold and provided more than two-thirds of the gold ever produced (Boyle, 1979: 333). In 1532, Atahualpa's gold ransom was evidence for the abundant placer, vein, and porphyry gold occurrences in the Andes (Petersen, 1970; Petersen et al., 1990; Noble \& Vidal, 1994; Cánepa, 2005) as well as the successful small-scale gold mining methods used before European contact. Porphyry ores produced a copper-gold-silver alloy or tumbaga, which, through depletion gilding or other treatments, resulted in enhanced surficial gold (Petersen, 1970: 57). Nuggets and coarse gold would have been recovered by gravity methods; however, recovering fine-grained placer or vein gold would have required initial gravity separation and then, as now, amalgamation.

Cinnabar was mined in Turkey more than 8000 years ago and was used as a pigment and retorted for mercury (Barnes \& Bailey, 1972; Yildiz \& Bailey, 1978: 5). Before the Christian era, mercury was known in Spain and the Moorish name of the mine «al-Ma'din» (Almaden) and the name of the metal «azogue» are still known and used in Latin America. By A. D. 77, Rome imported 4-5 metric tons (t) of mercury annually from the mines at Almaden that were used for gold amalgamation and small-scale mining (D'Itri \& D'Itri, 1977: 7).

One of the earliest written descriptions of amalgamation was given by al-Biruni —an $11^{\text {th }}$ century Persian scientist - the gold was processed from crushed ore, mercury was added to amalgamate the gold, the amalgam was recovered and burned in order to volatilize the mercury and recover the gold (al-Hassan \& Hill, 1986: 247). The use of mercury for amalgamation in the ancient world was questioned by Craddock (2000: 233) and he proposed that if mercury had been used, then low levels of mercury would be found in the analyses of the processed gold. Therefore, gold samples from Sardis were analyzed (SEM-EDX), and since no mercury was detected, Ramage \& Craddock (2000: 103-107) concluded that mercury had not been used.

\section{AVAILABILITY AND CHRONOLOGY OF CINNABAR AND MERCURY USE IN THE NEW WORLD}

Cinnabar mining dates to 1000 B. C. in Mexico (Consejo de Recursos Minerales, 1992: 21) and cinnabar occurrences are known in Central America (Roberts \& Irving, 1957: 169) where mercury was found in a tomb in Belize that dates to A. D. 900-1000 (Pendergast, 1982). There are cinnabar and mercury occurrences in Colombia (Lozano, 1987), Ecuador (Truhan et al., 2005: 197), Chile (McAllister et al., 1950) and Perú (Petersen, 1970: 29; Nuñez \& Petersen, 2002: 136). However, one of the world's largest cinnabar occurrences is at Huancavelica, Perú (Yates et al., 1955: 10; Brown, 2001: 467) and in ancient Perú cinnabar was used as a decoration on gold masks (Gordus \& Shimada, 1995) as a pigment on murals (Bonavia, 1985: 79; Brooks et al., 2008), as a cosmetic for the elite Inka women (Brown, 2001: 477) and for funeral preparations (Shimada \& Griffin, 2005). 
Powdered cinnabar was found in a mollusk shell that had been used to mix pigments at a pre-contact site near Ica, southern Perú (Petersen, 1970: 80).

Isotopic data on mercury in lake sediments, combined with ${ }^{14} \mathrm{C}$ dates, indicate that mercury mining at Huancavelica began around 1400 B. C. and that mercury production peaked at approximately 500 B. C. and at A. D. 1450, corresponding to the heights of Chavin and Inka rule, respectively, in the region (Cooke et al., 2009). Retorts were described (Petersen, 1970: 49; Burger \& Matos, 2002) and detrital mercury was found in drainages near Huancavelica (Arana, 1901: 6; Petersen, 1970: 29).

The Inka ( A. D. 1200-1533) recognized the health hazards of mercury and that exposure to mercury and cinnabar during mining and retorting would cause the ancient miners «to shake and lose their senses» and, therefore, the use of mercury by the Inka declined (Larco Hoyle, 2001: 135). At about the same time in Europe, Agrícola (1912 [1556]: 427) described methods for retorting mercury and workers were warned to turn their backs to the sweet smelling mercury fumes that would loosen their teeth.

However, after the Conquest, Spain transported mercury from the mines at Almaden, Spain, to be used for gold and silver processing in the New World. Spanish shipwrecks that still contain Almaden mercury are known in Colombia and the Dominican Republic (Petersen, 1979: 851). Upon «re-discovery» of the mercury occurrences at Huancavelica in 1566-1567 (Arana, 1901: 77; Larco Hoyle, 2001: 135; Nuñez \& Petersen, 2002: 137), which had earlier been mined by ancient peruvians (Cooke et al., 2009), imported spanish mercury was replaced by mercury that had been retorted from the rich cinnabar ore at Huancavelica. Mercury production data from 1570 to 1800 is compiled in Nuñez \& Petersen (2002: 138, 149). Dangerous mining conditions, cold, working at 4000 meters $(\mathrm{m})$, and exposure to the toxic mercury fumes caused Huancavelica to be known as the Mina de la muerte (Brown, 2001: 468). Regardless, mercury was essential for mineral processing in Spanish Colonial America and adding mercury, el azogado was an important step in Colonial silver production (Del Busto Duthurburu, 1996: 98).

Mercury from Huancavelica was also used in the «patio process» for silver amalgamation in Perú and Mexico (Núñez \& Petersen, 2002: 142). Salt, mercury, and vitriol (mixed copper and iron sulfates) were mixed with crushed silver ore in a large open area, or patio, which was basically a flat surface impervious to mercury. A variation, the «buytron process» was used at silver mines at Potosí, Bolivia, where the cold climate required heat from below to speed amalgamation and therefore, silver production (Crozier, 1993; Craddock, 1995: 216).

\section{GOLD AMALGAMATION IN ANCIENT PERÚ}

Mercury was known to the Chavin (700-500 B. C.) (Petersen, 1970: xix) and Larco Hoyle (2001: 128) indicated that mercury was used by the Moche ( 100 B. C.- 
A. D. 800) to amalgamate placer gold. Based on the large, rocker-like crushing stones, called quimbaletes or Inka mills, and quartz vein waste found at Hoabamba and other archaeological sites in Perú, Posnansky (in Petersen, 1970: 24) proposed that amalgamation was used before European contact. Mercury is widely used for modern quimbalete gold-processing (Cánepa, 2005: 49) and, therefore, it is logical that mercury was also used for gold-processing in the past (Brooks et al., 2009).

Alternatives to mercury, though not widely used, include the use of plant juices in Colombia (Castillo Espítia, 2007: 305) and Perú (Larco Hoyle, 2001: 138). Gold-bearing sands were dried, tossed into the air, which left a gold concentrate (Petersen, 1970: 26). Carpet and donkey skins, reminiscent of the Golden Fleece, are placed in the sluices and streams to trap the fine-grained gold in some parts of Perú (Walter Sologuren, geologist, Compañía Minera Poderosa, S. A., Lima, oral communication, October 31, 2008); however, the gold may then be further concentrated using mercury.

\section{FABRICATION AND MERCURY CONTENT}

In the central Andean metalworking area, which includes Colombia, Ecuador, and Perú, gold objects were more commonly shaped by hammering rather than by casting (Lechtman, 1988; Plazas, 2007). For example, anvils, gold foils, and stone hammers were found at a site in south-central Perú that dates to $1490 \pm 100 \mathrm{~B}$. C. (Grossman, 1972); however, the gold foils were not analyzed.

Using spectrographic analysis, Petersen (1970: 25,57) provided analytical data on native gold from several alluvial occurrences in Perú and a Chimú gold lip ornament, respectively. If the ornament had been hammered directly from native gold, then the mercury content of the native gold and the fabricated piece should be similar. However, there is a significant decrease in the mercury content of the fabricated Chimú ornament $(<100 \mathrm{ppm})$, compared to that of the native gold samples (1 000-10 000 ppm) that can only be explained by volatilization of the mercury.

Petersen's (1970: 25) analyses would ideally provide the background mercury content of the native gold; however, the mercury content may be the result of contamination from: 1) Mercury released from widespread use of mercury for Spanish Colonial mining; 2) Mercury released by ancient Andeans for gold amalgamation for several thousands of years (Brooks et al., 2009); 3) Detrital native mercury released over millions of years; or 4) Regional volcanism. Therefore, it is difficult to establish background mercury content using placer nugget composition and it is not possible to date the mercury enrichment in the nuggets.

\section{ANALYTICAL TECHNIQUES}

Because of the proximity of gold and mercury on the Periodic Chart and the low levels of mercury in the gold, neither SEM-EDX (Ramage \& Craddock, 2000: 103- 
107) nor XRF (Aldenderfer et al., 2008) would have provided sufficient analytical discrimination to detect the potentially low levels of mercury in the gold foils. In another study, elements in concentrations of less than 100 ppm in gold were detected by SEM-EDS; however, these elements were not reported (Rehren \& Temme, 1994). Therefore, replication of Petersen's sampling and ICP analysis will provide more precise data on the mercury content of nugget gold, amalgam, worked gold, and the mercury content of the end-product of the refogado process, the charapita, for comparison and interpretation.

On table 1, analyses of amalgam, refogado gold, a gold nugget and three charapitas of gold are presented. In order to establish the background mercury and other elemental content of gold-mineralized rock samples directly from the outcrop, samples from several mines in Perú were analyzed (table 2). The samples are from Pataz, in northern Perú, which is known to have produced placer gold since ancient time (Schreiber et al., 1990; Haeberlin et al., 2004) and the other is from the Costa Sur Media, Perú (Cánepa, 2005). No visible gold was present in either sample.

These crushed samples were also panned in order to obtain a gold concentrate with which to determine background elemental composition of the gold; however, the samples contained very fine-grained gold that would not yield a concentrate. The fine-grained gold cannot break the surface tension of the water, clings to the lower surface of the water, and is washed out of the gold pan (West, 1974: 21; Oyler, 1997). Background mercury content can be inferred from microprobe analyses of placer gold which show that the cores of placer gold do not contain mercury even though there is an amalgam rim of contaminant mercury released from placer mining (McCready et al., 2003).

On table 3 are compiled data on the mercury and elemental content of three samples of pre-contact gold foils from northern Perú and four samples of precontact gold foils from Colombia. These samples were analyzed by ICP in order to establish the mercury content of pre-contact gold and to refine the analytical data on the composition of pre-contact gold provided by Petersen (1970: 57).

The low levels of mercury in the gold foils from Perú and Colombia (table 3), are consistent with Craddock's (2000: 233) proposal that if mercury had been used to amalgamate gold in the ancient world, then low levels of mercury would be detected in the gold.

\section{CONTAMINATION}

Analyses of 872 samples from 364 ancient Peruvian gold artifacts, with surficial cinnabar powder, from a pre-contact burial showed that the mercury content ranged from 100000 to 300000 ppm (Gordus \& Shimada, 1995). They concluded that the mercury content was contaminant-mercury from the powdered cinnabar and was not an integral part of the gold. The mercury content of the pre-contact gold foil samples analyzed for this study is far below the contaminant-mercury 
Amalgamation and small-scale gold mining in the ancient Andes

Table 1 - ICP analyses of gold from Perú and Venezuela

\begin{tabular}{|c|c|c|c|c|c|c|c|c|}
\hline & PEa & PEr & PEc1 & PEc2 & PEc3 & VZn & VZa & VZr \\
\hline $\mathrm{Ag}$ & 1130 & 818 & 38700 & $>100$ & $>100$ & 2470 & 2510 & 2000 \\
\hline Al & 339 & 120 & 153 & 1040 & 948 & 819 & 177 & 582 \\
\hline As & 8 & 4 & 28 & 2,3 & 2,0 & 3 & 5 & 7 \\
\hline $\mathrm{Au}$ & 368000 & 368000 & 300000 & $>400$ & $>400$ & 296000 & 513000 & 742000 \\
\hline B & 228 & 163 & $<20$ & 1555 & 1425 & 110 & 186 & 221 \\
\hline $\mathbf{B a}$ & 4 & 0 & 7 & 17 & 12 & 0 & 2 & 2 \\
\hline $\mathbf{B i}$ & 0 & 0 & $<3$ & 0 & 0 & 0 & 0 & 7 \\
\hline $\mathrm{Ca}$ & 43 & 35 & $<100$ & 394 & 344 & 24 & 47 & 54 \\
\hline $\mathrm{Cd}$ & 0 & 0 & $<0,5$ & 0 & 0 & 0 & 0 & 0 \\
\hline Co & 1 & 1 & $<1$ & 0 & 0 & 0 & 0 & 0 \\
\hline $\mathrm{Cr}$ & 1 & 1 & $<1$ & 3 & 3 & 1 & 3 & 3 \\
\hline $\mathrm{Cu}$ & 7 & 6 & 126 & $>1000$ & $>1000$ & 1150 & 4580 & 280 \\
\hline $\mathrm{Fe}$ & 215 & 118 & 338 & 974 & 656 & 1360 & 94 & 239 \\
\hline $\mathrm{Hg}$ & 312000 & 822 & 8,3 & 37 & 1,2 & 3690 & 248000 & 96400 \\
\hline $\mathbf{K}$ & 7 & 0 & $<100$ & 395 & 243 & 1 & 1 & 0 \\
\hline $\mathrm{La}$ & 2 & 0 & 3 & 2 & 1 & 0 & 1 & 2 \\
\hline $\mathrm{Mg}$ & 9 & 34 & $<100$ & 1 & 1 & 30 & 36 & 27 \\
\hline Mn & 1 & 2 & 3 & 1 & 1 & 1 & 3 & 1 \\
\hline Mo & 0 & 0 & $<1$ & 1 & 1 & 0 & 0 & 3 \\
\hline $\mathrm{Na}$ & 9 & 8 & 184 & $>100$ & $>100$ & 9 & 8 & 12 \\
\hline $\mathrm{Ni}$ & 3 & 6 & 3 & 3 & 5 & 5 & 4 & 6 \\
\hline $\mathbf{P}$ & 27 & 7 & 16 & 1 & 1 & 5 & 7 & 21 \\
\hline $\mathrm{Pb}$ & 83 & 514 & $<3$ & 1 & 1 & 5 & 58 & 61 \\
\hline$S$ & 9 & 5 & $<500$ & 10 & 10 & 18 & 8 & 29 \\
\hline $\mathbf{S b}$ & 9 & 16 & $<3$ & 1 & 14 & 3 & 7 & 9 \\
\hline $\mathrm{Se}$ & 1 & 1 & $<5$ & 3 & 7 & 0 & 0 & 4 \\
\hline $\mathrm{Sr}$ & 5 & 13 & 44 & 4 & 2 & 12 & 7 & 12 \\
\hline Th & 2 & 2 & $<3$ & 1 & 1 & 0 & 1 & 2 \\
\hline $\mathbf{T i}$ & 38 & 11 & $<100$ & 6 & 4 & 36 & 2 & 8 \\
\hline $\mathrm{Tl}$ & 0 & 0 & $<5$ & 1 & 1 & 0 & 0 & 0 \\
\hline $\mathbf{U}$ & 0 & 0 & $<8$ & 1 & 1 & 0 & 1 & 1 \\
\hline $\mathrm{V}$ & 1 & 0 & $<1$ & 1 & 1 & 3 & 1 & 1 \\
\hline $\mathrm{W}$ & 2 & 2 & $<2$ & 1 & 1 & 1 & 2 & 2 \\
\hline $\mathrm{Zn}$ & 4 & 2 & $<1$ & 2 & 2 & 3 & 3 & 6 \\
\hline
\end{tabular}

PEa: unburned amalgam, Las Quebradas mining camp, Huepethue, Madre de Dios, Perú

PEr: refogado gold after two burns in the field at Las Quebradas

PEc1-3: charapitas: 1) From a gold shop in Puerto Maldonado, Madre de Dios, Perú; 2-3) From a gold dealer in Lima, also from Madre de Dios

No gold nuggets were available in the Madre de Dios area

VZn: gold nugget from the km 88 mining district, Estado Bolívar, Venezuela (Brooks et al., 1995)

VZa: unburned amalgam from $\mathrm{km} 88$

VZr: gold that has been burned (refogado) once in a gold shop in km 88

Inductively Coupled Plasma analysis, in parts per million (ppm), by American Assay Laboratories, Sparks, NV 
Table 2 - ICP analyses of gold ore from mines at Nazca and Pataz, Perú

\begin{tabular}{|c|c|c|c|}
\hline & $\mathrm{NZ}$ & PTZw & PTZo \\
\hline Ag & 59 & 8 & 51 \\
\hline $\mathrm{Al}$ & 6350 & 4910 & 4070 \\
\hline As & 1238 & 3900 & 13400 \\
\hline Au & 7 & 23 & 26 \\
\hline B & $<20$ & $<20$ & $<20$ \\
\hline $\mathrm{Ba}$ & 5 & 27 & 19 \\
\hline $\mathbf{B i}$ & 51 & 3 & $<3$ \\
\hline $\mathrm{Ca}$ & 1333 & 17400 & 7300 \\
\hline Cd & 3 & 10 & 54 \\
\hline Co & 700 & 9 & 11 \\
\hline $\mathrm{Cr}$ & 15 & 11 & 12 \\
\hline $\mathrm{Cu}$ & 76439 & 78 & 120 \\
\hline $\mathrm{Fe}$ & 239111 & 63628 & 176806 \\
\hline $\mathrm{Hg}$ & 0,373 & 0,098 & 0,404 \\
\hline K & 244 & 2680 & 2390 \\
\hline $\mathrm{La}$ & 2 & 6 & 3 \\
\hline $\mathrm{Mg}$ & 3636 & 1776 & 2700 \\
\hline Mn & 724 & 392 & 1030 \\
\hline Mo & 3 & 12 & 11 \\
\hline $\mathrm{Na}$ & 521 & 435 & 208 \\
\hline $\mathrm{Ni}$ & 65 & 6 & 11 \\
\hline $\mathbf{P}$ & 250 & 204 & 249 \\
\hline $\mathrm{Pb}$ & 365 & 939 & 17983 \\
\hline$S$ & 1170 & 48122 & 164783 \\
\hline $\mathrm{Sb}$ & $<3$ & $<3$ & 19 \\
\hline $\mathrm{Se}$ & $<5$ & $<5$ & $<5$ \\
\hline $\mathrm{Sr}$ & 12 & 15 & 8 \\
\hline Th & $<3$ & $<3$ & $<3$ \\
\hline $\mathrm{Ti}$ & $<100$ & $<100$ & $<100$ \\
\hline $\mathrm{Tl}$ & $<5$ & $<5$ & $<5$ \\
\hline $\mathbf{U}$ & $<8$ & $<8$ & $<8$ \\
\hline $\mathrm{V}$ & 23 & $<1$ & $<1$ \\
\hline $\mathbf{W}$ & $<2$ & 19 & $<2$ \\
\hline $\mathrm{Zn}$ & 189 & 1120 & 5890 \\
\hline
\end{tabular}

NZ: outcrop sample, Nazca, Costa Sur Media, Perú and has not been in contact with mercury

PTZw: outcrop sample, Pataz, La Libertad, northern Perú and has not been in contact with mercury

PTZo: ore concentrate, also from Pataz

Inductively Coupled Plasma analysis, in parts per million (ppm), by American Assay Laboratories, Sparks, NV 
Amalgamation and small-scale gold mining in the ancient Andes

Table 3 - ICP analyses of pre-contact gold from Perú and Colombia

\begin{tabular}{|c|c|c|c|c|c|c|c|}
\hline & MNA1 & MNA2 & MNA3 & CP1 & CP2a & CP2b & CP3 \\
\hline $\mathrm{Ag}$ & 28500 & 41300 & 32700 & 44972 & 26562 & 16062 & 6382 \\
\hline $\mathrm{Al}$ & 645 & 135 & 121 & 118 & 354 & 308 & 179 \\
\hline As & 14800 & 5900 & 15500 & 1 & 1 & 1 & 1 \\
\hline $\mathbf{A u}$ & 190000 & 208000 & 178000 & 332947 & 897992 & 896677 & 329997 \\
\hline B & 301 & 117 & 92 & 200 & 200 & 200 & 200 \\
\hline $\mathrm{Ba}$ & 11 & 3 & 4 & 1 & 1 & 1 & 1 \\
\hline $\mathbf{B i}$ & 3 & 165 & 95 & 7 & 1 & 1 & 1 \\
\hline $\mathrm{Ca}$ & 1500 & 1260 & 983 & 139 & 239 & 186 & 1214 \\
\hline $\mathrm{Cd}$ & $<0,5$ & $<0,5$ & $<0,5$ & 0,02 & 0,03 & 0,11 & 0,02 \\
\hline Co & 14 & 4 & 56 & 1 & 1 & 1 & 1 \\
\hline $\mathrm{Cr}$ & $<1$ & $<1$ & $<1$ & 0,5 & 1,9 & 1,0 & 0,5 \\
\hline $\mathrm{Cu}$ & 665000 & 700000 & 800000 & 610337 & 38500 & 49400 & 659461 \\
\hline $\mathrm{Fe}$ & 93817 & $<100$ & $<100$ & 111 & 418 & 263 & 103 \\
\hline $\mathrm{Hg}$ & 13,8 & 12,3 & 13,9 & 1 & 2 & 9 & 12 \\
\hline $\mathbf{K}$ & 413 & 202 & $<100$ & 134 & 129 & 130 & 312 \\
\hline $\mathbf{L a}$ & $<1$ & $<1$ & $<1$ & 1 & 1 & 1 & 1 \\
\hline $\mathrm{Mg}$ & 323 & 336 & $<100$ & 12 & 28 & 21 & 26 \\
\hline Mn & $<2$ & 4 & 1028 & 0,2 & 3,2 & 2,0 & 0,5 \\
\hline Mo & $<1$ & $<1$ & 10 & 1 & 1 & 1 & 1 \\
\hline $\mathrm{Na}$ & 3180 & 2740 & 753 & 877 & 965 & 1145 & 1675 \\
\hline $\mathrm{Ni}$ & 280 & 208 & 322 & 4 & 4 & 3 & 2 \\
\hline $\mathbf{P}$ & 24 & $<10$ & $<10$ & 5 & 5 & 5 & 1675 \\
\hline $\mathrm{Pb}$ & 114 & 126 & 107 & 7,1 & 12,6 & 4,1 & 8,5 \\
\hline $\mathbf{P t}$ & na & na & na & 46 & 12 & 3 & 43 \\
\hline$S$ & 2190 & $<500$ & $<500$ & 58 & 14 & 93 & 229 \\
\hline $\mathrm{Sb}$ & 59 & 120 & 111 & 5 & 12 & 9 & 6 \\
\hline $\mathrm{Se}$ & 40 & 48 & 46 & 2 & 2 & 2 & 2 \\
\hline $\mathrm{Sr}$ & 8 & 17 & 8 & 0,7 & 1,1 & 0,8 & 5,8 \\
\hline Th & 5 & 8 & 5 & 1 & 1 & 1 & 1 \\
\hline $\mathrm{Ti}$ & $<100$ & $<100$ & $<100$ & 0,7 & 3,1 & 3,4 & 2,1 \\
\hline $\mathrm{Tl}$ & $<5$ & $<5$ & $<5$ & 2 & 1 & 1 & 1 \\
\hline $\mathbf{U}$ & $<8$ & $<8$ & $<8$ & 2 & 2 & 2 & 2 \\
\hline $\mathrm{V}$ & 47 & 26 & 24 & 2,1 & 0,4 & 0,6 & 2,9 \\
\hline $\mathbf{W}$ & $<2$ & $<2$ & $<2$ & 1 & 5 & 4 & 1 \\
\hline $\mathrm{Zn}_{\mathrm{n}}$ & 51 & 13 & 10 & 11 & 22 & 14 & 7 \\
\hline
\end{tabular}

MNA1-3: Middle Sicán (A. D. 900-1200) gold foil samples, Huaca de la Ventana, Lambayeque, Perú (Carcedo Muro \& Shimada, 1985: 62); obtained from Dra. Carmen Arellano Hoffman, Museo Nacional de Arqueología, Antropología e Historia del Perú, Lima

CP1: fragment of a pre-contact nose ornament, location unknown

CP2a-b: pre-contact beads, Calima region, 200 B. C.-A. D. 1000, southwestern Colombia CP3: pre-contact disc, Tairona region, A. D. 800-1500, northeastern Colombia

Samples were identified by and obtained from Dra. Clemencia Plazas, Universidad Nacional de Colombia, Bogotá

Inductively Coupled Plasma analysis, in parts per million (ppm) by American Assay Laboratories, Sparks, NV —indicates at or below detection, na- not analyzed 
range of 100 000-300 000 ppm and is consistent with, and comparable to, the amount of mercury present in charapita gold from the modern amalgamationrefogado process.

The mercury content of the Chimú artifact, <100 ppm, analyzed by Petersen (1970: 57) is also far below the contaminant range established by Gordus \& Shimada (1995). Microprobe analyses of placer gold indicate that the native mercury released during small-scale mining in $18^{\text {th }}$ century Argentina is not pervasive and is limited to the rim of the placer gold grain (McCready et al., 2003). This indicates that any tomb-related cinnabar contamination would have been similarly limited to the surface of the gold artifact and would have been removed during cleaning at the respective museums.

\section{INTERPRETATION}

Craddock's (2000: 233) proposal was tested and has a modern analog in that refogado gold, from Madre de Dios, that was amalgamated and then burned twice in the field, with a third and final burn at the gold shop, resulted in charapitas of gold with an average mercury content of 15 ppm. The ICP analytical data from this field study and other referenced analytical data, including INAA analysis of a pre-contact gold foil from Ecuador, are compiled on table 4. The low mercury content of these samples, with an average of 9 ppm mercury, is consistent with amalgamation and burning the gold samples in the ancient Andes as is done today at small-scale mines in Perú, Colombia and Ecuador. The low mercury content ( $<100$ ppm) of the Chimú sample analyzed by Petersen (1970: 57) is also consistent with this interpretation.

The decrease in mercury content from 1,000 to 10,000 ppm mercury in native gold nuggets from Perú (Petersen, 1970: 25) to 12,3-13,9 ppm in the Sicán samples from this study, or from $\sim 300000$ ppm in unburned amalgam to 8 ppm after three burns as indicated by the gold shop sample, can be explained by re-interpretation of the technique shown in the Benzoni woodcut (Petersen, 1970: 84).

Even though the Benzoni woodcut dates to the late 1500s, it provides graphic detail on the final stages of gold processing in the New World. It is commonly assumed that the blowpipes or sopletes were used to blow on the coals at the base of the flames; however, this would not beautify the gold in the crucible, only melt it. As proposed herein, the sopletes were used as blowpipes to focus the flame directly onto the gold in the crucible. This technique would have produced a very hot, focused flame, $\sim 1500{ }^{\circ} \mathrm{C}$, just beyond the visible portion of the flame and would have produced gold that is very bright and reflective (Hurlbut, 1971: 205). This would have added to the aesthetic appeal of gold which, in the ancient Andes, was believed to be tears from the sun or lágrimas del sol.

Ancient Colombian metallurgists routinely worked platinum using only a soplete, yet platinum was not smelted in Europe until the late 1800s (Bray, 1988). The soplete was used in ancient Colombia to achieve the temperatures needed to 
Amalgamation and small-scale gold mining in the ancient Andes

Table 4 - Summary of mercury content

\begin{tabular}{|c|c|c|c|c|}
\hline Host rock and ore & $\begin{array}{c}\text { Native Au nugget, } \\
\text { river }\end{array}$ & $\begin{array}{l}\text { Unburned } \\
\text { amalgam }\end{array}$ & $\begin{array}{l}\text { Refogado or } \\
\text { burned gold }\end{array}$ & Pre-contact gold \\
\hline $\begin{array}{c}\text { 0,373 } \mathrm{ppm} \mathrm{Hg}^{1} \text {, ore, } \\
\text { Nazca, Perú } \\
\text { (table 2, this study) }\end{array}$ & $\begin{array}{l}3690 \mathrm{ppm} \mathrm{Hg}^{1} \text {, } \\
\mathrm{km} 88 \text {, Venezuela } \\
\text { (table 1, this study) }\end{array}$ & $\begin{array}{l}312000 \text { ppm Hg1, } \\
\text { Huepethue, } \\
\text { Madre de Dios, } \\
\text { Perú } \\
\text { (table 1, this study) }\end{array}$ & $\begin{array}{c}15 \mathrm{ppm} \text { average } \\
\mathrm{Hg}^{1} \text {, final gold } \\
\text { shop burn, Puerto } \\
\text { Maldonado, Perú, } 3 \\
\text { samples } \\
\text { (table 1, this study) }\end{array}$ & $\begin{array}{c}\text { 12,3 to } 13,9 \mathrm{ppm} \mathrm{Hg} \text {, } \\
\text { Sicán, } \\
\text { A. D. } 900-1200, \\
\text { Lambayeque, Perú, } \\
3 \text { samples } \\
\text { (table 3, this study) }\end{array}$ \\
\hline $\begin{array}{c}\text { 0,098 ppm } \mathrm{Hg}^{1}, \\
\text { host rock, } 0.404 \\
\text { ppm } \mathrm{Hg}^{1}, \text { ore, } \\
\text { Pataz, Perú } \\
\text { (table 2, this study) }\end{array}$ & $\begin{array}{l}5000 \text { ppm Hg } \\
\text { average, } \\
500 \text { analyses, } \\
\text { Argentina } \\
\text { (Márquez-Zavalía } \\
\text { et al., 2004) }\end{array}$ & $\begin{array}{l}248000 \mathrm{ppm} \mathrm{Hg}^{1} \text {, } \\
\mathrm{km} 88 \text {, Venezuela } \\
\text { (table } 1 \text {, this study) }\end{array}$ & $\begin{array}{c}822 \mathrm{ppm} \mathrm{Hg} 1 \\
\text { two burns, } \\
\text { Huepethue, Madre } \\
\text { de Dios, Perú } \\
\text { (table 1, this study) }\end{array}$ & $\begin{array}{c}\text { 1-12 ppm Hg}{ }^{1}, \\
\text { 200 B. C.-A. D. } 1500, \\
\text { Colombia, } \\
4 \text { samples } \\
\text { (table } 3 \text {, this study) }\end{array}$ \\
\hline $\begin{array}{l}\text { 2-3 ppm Hg, ore, } \\
\text { Pierina, Perú, } \\
\text { (M. Merry, manager, } \\
\text { Barrick, written } \\
\text { communication, } \\
\text { oct. 24, 2008) } \\
\end{array}$ & $\begin{array}{c}765-5350 \mathrm{ppm} \\
\mathrm{Hg} \text {, placer nuggets, } \\
\text { Canada (Boyle, 1979: } \\
127)\end{array}$ & & $\begin{array}{c}96400 \text { ppm } \mathrm{Hg}^{1}, \\
\text { single burn, } \\
\mathrm{km} 88 \text {, Venezuela } \\
\text { (table 1, this study) }\end{array}$ & $\begin{array}{c}15 \text { ppm Hg} \text {, } \\
\text { Early Tolita, } \\
\text { 918-780 B. C., } \\
\text { Las Balsas, Ecuador, } \\
1 \text { sample } \\
\text { (Valdez et al., 2005) }\end{array}$ \\
\hline $\begin{array}{c}25 \text { ppm Hg, } \\
\text { ore, } \\
\text { Carlin, Nevada, } \\
\text { (Radtke } \text { et al., 1972) }\end{array}$ & $\begin{array}{c}1000-10000 \mathrm{ppm} \\
\mathrm{Hg}^{3} \\
\text { Sandia, Perú } \\
\text { (Petersen, 1970: 47) }\end{array}$ & & & $\begin{array}{l}\text { <100 ppm Hg} 3, \\
\text { Chimú, } \\
\text { A. D. 800-1400, } \\
\text { Piura, Perú, } \\
1 \text { sample } \\
\text { (Petersen, 1970: 57) }\end{array}$ \\
\hline
\end{tabular}

1 Inductively Coupled Plasma (ICP) analysis, in parts per million (ppm), by American Assay Laboratories, Sparks, NV. Complete analyses are given on tables 1-3, this study

2 Instrumental neutron activation analysis (INAA)

${ }_{3}^{3}$ Spectrographic chemical analysis

sinter gold, which melts at $>1000{ }^{\circ} \mathrm{C}$, and platinum, which melts at $>1700{ }^{\circ} \mathrm{C}$ (Petersen, 1970: 55, 63). And, in an ancient storehouse near Cusco, Perú, copper and ceramic sopletes of many different sizes were found (Petersen, 1970: 37).

The low mercury content of Petersen's Chimú gold sample (Petersen, 1970: 57) is consistent with volatilization of the mercury by burning the gold. Today, this refogado process is used by many small-scale miners in Perú, where a gas torch, also referred to as a soplete, is used to volatilize the mercury and improve the appearance of the gold (Brooks et al., 2007: 15). The refogado process is widely used by small-scale miners in many other regions of South America.

\section{CONCLUSION}

The use of mercury for small-scale gold mining in the ancient Andes is consistent with a global chronology of cinnabar mining and retorting. Given, that cyanide 
methods for gold recovery were not used until the late 1880s, then amalgamation technology explains how gold foils were produced in the ancient Andes. The availability of cinnabar and mercury in the region, specifically at Huancavelica where pre-contact mining took place and retorting vessels have been found, also supports this conclusion. The presence of ancient quimbaletes and quartz vein waste indicates that mercury was used then, as it is used now, to concentrate finegrained gold. Re-consideration of the ancient soplete method to direct a hot flame onto the amalgam to volatilize the mercury and beautify the gold has a modern analogy in the use of the gas torch.

Results of this study that show that the multi-step refogado process used by smallscale miners in modern Perú is very efficient in reducing the mercury content of unburned amalgam from approximately 300000 ppm in the field to approximately 15 ppm after the final burn in the gold shop. The quantity of mercury in the modern charapitas is comparable to the low mercury content of ancient gold foils from Perú, Colombia and Ecuador and is consistent with the interpretation that a similar amalgamation-refogado process was used in the ancient Andes for gold mining and production before european contact.

\section{Cited References}

AGRíCOLA, G., 1556 - De Re Metallica, 638 pp.; New York: Dover Publications. A translation by H. C. Hoover \& L. H. Hoover, 1912.

ALDENDERFER, M., CRAIG, N. M., SPEAKMAN, R. J. \& POPELKA-FILCOFF, R., 2008 Four thousand year old gold artifacts from the Lake Titicaca basin, southern Perú. Proceedings of the National Academy of Sciences, 105 (13): 5002-5005.

AL-HASSAN, A. Y. \& HILL, D. R., 1986 - Islamic technology, an illustrated history, 304 pp.; Cambridge: Cambridge University Press.

ARANA, P. P., 1901 - Las minas de azogue del Perú, 109 pp.; Lima: Imprenta El Lucero.

BARNES, J. W. \& BAILEY, E. H., 1972 - Turkey's major mercury mine today and how it was mined 8000 years ago. World Mining, 25 (4): 49-55.

BONAVIA, D., 1985 - Mural painting in ancient Perú, 224 pp.; Bloomington: Indiana University Press.

BOYLE, R. W., 1979 - The geochemistry of gold and its deposits, 584 pp.; Ontario: Ottawa Press. Canadian Geological Survey Bulletin, 280.

BRAY, W., 1988 - Resolving the platinum paradox. Americas, 40 (6): 45-49.

BROWN, K. W., 2001 - Workers' health and colonial mercury mining at Huancavelica (Perú). The Americas. The Academy of American Franciscan History, 57 (4): 467496.

BROOKS, W. E., GUERRA, A. \& NUÑEZ, F., 1995 - Gold resources of the Rio Chivao study area, Estado Bolívar, Venezuela. U.S. Geological Survey Bulletin, 2124: H1-H5.

BROOKS, W. E., SANDOVAL, E., YEPEZ, M. \& HOWARD, H., 2007 - Perú mercury inventory 2006. U.S. Geological Survey Open-File Report, 1252. Disponible en: $<$ http://pubs.usgs.gov/of/2007/1252/> 
BROOKS, W. E., PIMICHUMO, V., SUÁREZ, H., JACKSON, J. C. \& MCGEEHIN, J. P., 2008 - Mineral pigments from Huaca Tacaynamo (Chan Chan, Perú). Bulletin de I'Institut Français d'Études Andines, 37 (3): 1-10; Lima: Instituto Francés de Estudios Andinos.

BROOKS, W. E., SCHWORBEL, G. \& CASTILLO, L. E., 2009 - Mercury and small-scale gold mining in the ancient Andes. Geological Society of America Annual Meeting, Abstracts with Programs, 41 (7): 435.

BURGER, R. L. \& MATOS, R., 2002 - Atalla, a center on the periphery of the Chavin Horizon. Latin American Antiquity, 13 (2): 10-25.

BUSTO DUTHURBURU del, J. A., 1996 - La platería en el Perú, 357 pp.; Lima: Colección Enrico Poli, Banco Sur del Perú, Cuzzi y Cia, S.A.

CÁNEPA, C., 2005 - Minería a pequeña escala en la costa sur media del Perú, 79 pp.; Lima: Dirección de Geología Económica y Prospección Minera, Boletín 3, Serie E: Minería, Instituto Geológico Minero y Metalúrgico.

CARCEDO MURO, P. \& SHIMADA, I., 1985 - Behind the gold mask, Sicán gold objects from Batan Grande, Perú. In: The Art of Precolumbian Gold (J. Jones, ed.): 60-75; New York: The Jan Mitchell Collection, Graphic Society.

CASTILLO ESPÍTIA, N., 2007 - Minería aurífera en el noroeste andino de Colombia, etnografía de la técnica. In: Metalurgia en la América Antigua (R. Lleras Pérez, ed.): 281-321; Bogotá: Fundación de Investigaciones Arqueológicas Nacionales, Banco de la República, Instituto Francés de Estudios Andinos.

CONSEJO DE RECURSOS MINERALES, 1992 - Geological mining monograph of the State of Queretaro, Mexico, 108 pp.; México, D.F.: Consejo de Recursos Minerales, Secretaría de Energía, Minas e Industria Paraestatal, M-4e.

COOKE, C. A., BALCOM, P. H., BIESTAR, H. \& WOLFE, A. P., 2009 - Over three millennia of mercury pollution in the Peruvian Andes. Proceedings of the National Academy of Sciences, 106 (22): 8830-8834.

CRADDOCK, P. T., 1995 - Early metal mining and production, 363 pp.; Washington, D.C: Smithsonian Institution Press.

CRADDOCK, P. T., 2000 - Early history of the amalgamation process, appendix 3. In: King Croesus' Gold (A. Ramage \& P. T. Craddock, eds.): 233-237; London: British Museum Press.

CROZIER, R. D., 1993 - Silver processing in Spanish America, the patio and buytron processes. Canadian Mining and Metallurgical Bulletin, 86 (972): 86-91.

D'ITRI, P. A. \& D'ITRI, F. M., 1977 - Mercury contamination, a human tragedy, 311 pp.; New York: John Wiley and Sons.

GORDUS, A. A. \& SHIMADA, I., 1995 - Neutron activation analysis of microgram samples from 364 gold objects from a Sicán burial site in Perú, Materials Issues in Art and Archaeology IV. In: Materials Research Society Proceedings (P. B. Vandiver et al., eds.), 352: 127-142.

GROSSMAN, J. W., 1972 - An ancient gold worker's tool kit. Archaeology, 25 (4): 270-275.

HAEBERLIN, Y., MORITZ, R. \& FONTEBOTE, L., 2004 - Carboniferous orogenic gold deposits at Pataz, eastern Andean cordillera, Perú. Economic Geology, 99: 73-112.

HURLBUT, C. S., 1971 - Dana's manual of mineralogy (18 ${ }^{\text {th }}$ ed.), 579 pp.; New York: John Wiley and Sons.

LARCO HOYLE, R., 2001 - Los Mochicas, t. II, 350 pp.; Lima: Museo Arqueológico Rafael Larco Herrera. 
LECHTMAN, H., 1988 - Traditions and styles in central Andean metalworking. In: The Beginning of the Use of Metals and Alloys (R. Maddin, ed.): 344-378; Boston: Massachusetts Institute of Technology Press.

LOZANO, H., 1987 - Minerales de mercurio. In: Recursos Minerales de Colombia, Metales (A. Villegas Betancourt, ed.), t. I: 275-294; Bogotá: Publicaciones Geológicas Especiales del INGEOMINAS, 1.

MÁRQUEZ-ZAVALÍA, M. F., SOUTHAM, G., CRAIG, J. R. \& GALLISKI, M. A., 2004 Morphological and chemical study of placer gold from the San Luis Range, Argentina. The Canadian Mineralogist, 42: 169-182.

MCALLISTER, J. F., FLORES, H. \& RUIZ, C., 1950 - Quicksilver deposits of Chile. U.S. Geological Survey Bulletin, 964-E: 361-400.

MCCREADY, A. J., PARNELL, J. \& CASTRO, L., 2003 - Crystalline placer gold from the Rio Neuquen, Argentina, implications for the gold budget in placer gold formation. Economic Geology, 98 (3): 623-633.

NOBLE, D. C. \& VIDAL, C. E., 1994 - Gold in Perú. Society of Economic Geologists Newsletter, 17: 6-13.

NUÑEZ, E. \& PETERSEN, G., 2002 - Alexander von Humboldt en el Perú, Diario de viaje y otros escritos, 311 pp.; Lima: Banco Central de Reserva del Perú, Goethe Institut Inter Nationes.

OYLER, K., 1997 - Screen mesh sizes. Reprinted from The Gold Nugget, April 1997. Disponible en: <http://www.lornet.com/prospector/articles/screensmesh.htm>

PENDERGAST, D. M., 1982 - Ancient Maya mercury. Science, 217 (6): 533-535.

PETERSEN, G., 1970 - Mining and metallurgy in ancient Perú, 97 pp.; Boulder, C.O.: Geological Society of America Special Paper, 467. A translation by W. E. Brooks, 2010, of Minería y Metalurgia en el Antiguo Perú, Arqueológicas 12, Publicaciones del Instituto de Investigaciones Antropologícas, Museo Nacional de Antropología y Arqueología, Pueblo Libre, Lima, Perú.

PETERSEN, M., 1979 - Graveyard of the quicksilver galleons. National Geographic, 156 (6): 850-876.

PETERSEN, U., VIDAL, C. E. \& NOBLE, D. C., 1990 - A special issue devoted to the mineral deposits of Perú. Economic Geology, 85 (7): 1-289.

PLAZAS, C., 2007 - La metalurgia del área intermedia sur dentro del panorama americano. International Journal of South American Archaeology, 1: 33-38.

RADTKE, A. S., HEROPOULOS, C. C., FABBI, B. P., SCHEINER, B. J. \& ESSINGTON, N. M., 1972 - Data on major and minor elements in host rocks and ores, Carlin gold deposit, Nevada. Economic Geology, 67 (7): 975-978.

RAMAGE, A. \& CRADDOCK, P. T., 2000 - King Croesus' gold, 272 pp.; London: British Museum Press.

REHREN, T. \& TEMME, M., 1994 - Pre-Columbian gold processing at Putushio, southern Ecuador. In: Archaeometry of Pre-Columbian Sites and Artifacts (D. A. Scott \& P. Meyers, eds.): 267-284; Los Ángeles: UCLA Institute of Archaeology and the Getty Conservation Institute.

ROBERTS, R. J. \& IRVING, E. M., 1957 - Mineral deposits of Central America, 205 pp.; U.S. Geological Survey Bulletin, 1034.

SCHREIBER, D. W., FONTEBOTE, L. \& LOCHMAN, D., 1990 - Geologic setting, paragenesis, and physicochemistry of gold-quartz veins hosted by plutonic rocks in the Pataz region. Economic Geology, 95 (3): 1328-1347. 
SHIMADA, I. \& GRIFFIN, J. A., 2005 - Precious metal objects of the Middle Sicán. Scientific American, 15 (1): 80-89.

TRUHAN, D. L., BURTON, J. H. \& BRUHNS, K. O., 2005 - El cinabrio en el mundo Andino. Revista de Antropología, 18: 193-205; Cuenca: La Casa de La Cultura Ecuatoriana Benjamín Carrión.

VALDEZ, F., GRATUZE, B., YEPEZ, A. \& HURTADO, J., 2005 - Evidencia temprana de metalurgia en la Costa Pacífica ecuatorial. Boletín del Museo del Oro, 53; Bogotá: Banco de la República. Disponible en: < http://www.banrep.gov.co/museo/esp.boletin>

WEST, J. M., 1974 - How to mine and prospect for placer gold, 43 pp.; Denver, C.O.: U.S. Bureau of Mines Information Circular, 8517.

YATES, R. G., KENT, D. F. \& CONCHA, J. F., 1955 - Geology of the Huancavelica quicksilver district, Perú, 43 pp.; Washington, D.C.: U.S. Geological Survey Bulletin, 975A.

YILDIZ, M. \& BAILEY, E. H., 1978 - Mercury deposits in Turkey, 80 pp.; Washington, D.C.: U.S. Geological Survey Bulletin, 1456. 